\title{
Gastrointestinal Parasites of Free-Range Chickens - A Worldwide Issue
}

\author{
João LOZANO ${ }^{1,2^{*}}$, Adriana ANAYA ${ }^{3}$, Antonio Palomero SALINERO ${ }^{4}$, Estevam Guilherme LUX HOPPE ${ }^{5}$, \\ Lídia GOMES ${ }^{1}$, Adolfo PAZ-SILVA ${ }^{4}$, Maria Teresa REBELO ${ }^{6}$, Luís MADEIRA DE CARVALHO ${ }^{1}$ \\ ${ }^{1}$ CIISA - Animal Health Interdisciplinary Research Center, Faculty of Veterinary Medicine, University of \\ Lisbon, Lisbon, Portugal \\ ${ }^{2}$ Department of Plant Biology, Faculty of Sciences, University of Lisbon, Lisbon, Portugal \\ ${ }^{3}$ Research Group in Veterinary Medicine and Zootechnics (GIDIMEVETZ), Universidad Pedagógica y \\ Tecnológica de Colombia, Colombia \\ ${ }^{4}$ COPAR Research Group, Faculty of Veterinary Medicine, University of Santiago de Compostela, Spain \\ ${ }^{5}$ LabEPar - Laboratory of Parasitic Diseases, Universidade Estadual Paulista - UNESP, Faculdade de \\ Ciências Agrárias e Veterinárias, São Paulo State, Brazil \\ ${ }^{6}$ CESAM - Centre for Environmental and Marine Research, Department of Animal Biology, Faculty of \\ Sciences, University of Lisbon, Lisbon, Portugal \\ *corresponding author: joao.lozano@sapo.pt
}

Bulletin UASVM Veterinary Medicine 76(2)/2019

Print ISSN 1843-5270; Electronic ISSN 1843-5378

doi:10.15835/buasvmcn-vm:2019.0019

\begin{abstract}
:
Gastrointestinal parasites with direct and/or indirect life cycles, namely Eimeria spp., Ascaridia galli, Heterakis gallinarum and Capillaria spp., are responsible for the most frequent and heavy economic losses in aviculture. The current review aimed to collect information about gastrointestinal parasites affecting poultry, as well as, research studies regarding parasitic diseases in free-range chicken production. From the references used in this review, $20 \%$ highlight research studies correlating prevalence of gastrointestinal parasites in free-range chickens and factors such as the production system, age and animal density, hygienic conditions and weather.

Coccidiosis is responsible for the major economic losses in poultry farms. Diseases have different clinical signs and result in variable impacts on animals. Control programs include mainly vaccination, anti-coccidia and anthelminthic drugs, as well as, house cleaning and disinfection. This review concluded that coccidia and helminths are a global threat to free-range poultry production. More research in this area is necessary in order to understand the major factors influencing the prevalence of parasitic diseases in this type of poultry production. Also the search for new control strategies must be a priority, mainly using natural antiparasitic compounds and biological control approaches.
\end{abstract}

Keywords: Free-Range Chicken, Gastrointestinal Parasites, Animal Health Programs

Free-Range Chicken - Production and Health Problems

Poultry production is divided into two main different productive systems: intensive/indoor and free-range/outdoor (Permin and Hansen,
1998). Consumer plays a significant role on the evolution of some production systems. For example, in European countries like Portugal, episodes such as the avian flu and the antibiotic crisis of nitrofurans, led to a dramatic change on 


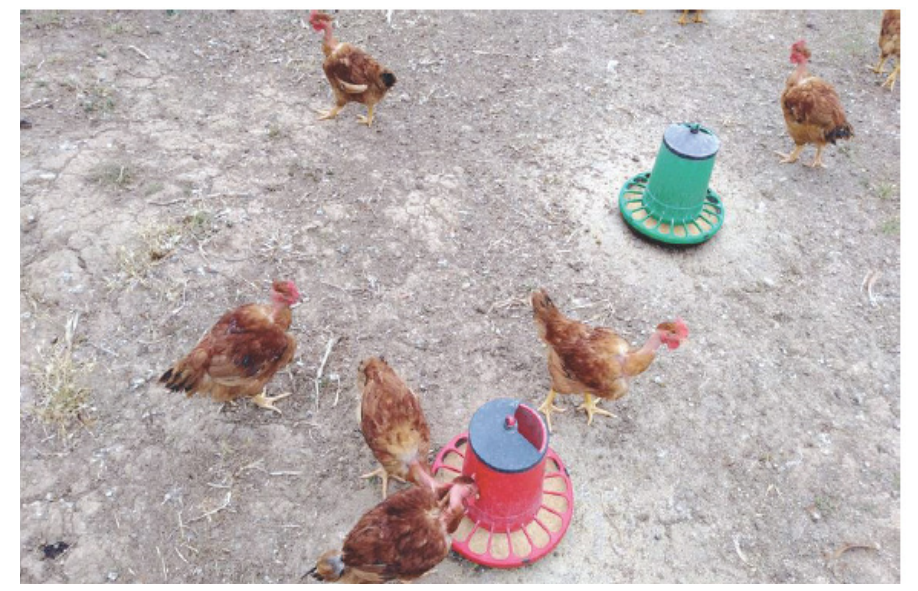

Figure 1. Free-range chickens from an agricultural-livestock farm in Lisbon.

the way consumer leads with its daily nutrition and increased awareness to themes like food quality and safety (Baptista, 2010). As a result, it was necessary to develop an alternative poultry production system, which would end in an healthier and more natural final product, giving consequently more confidence to consumers: Free-Range Chicken Production (Filho et al., 2003).

On this system (Figure 1), chickens have access to the outdoor environment in more than $50 \%$ of their life time, which totalizes an average of 3 months (Lozano and Mourato, 2016). This aspect highlights the need to a more awareness to animal health, due to the fact that chickens are exposed to a high load of parasites, by ingesting them from the environment and/or through their intermediate hosts (Baptista, 2010).

\section{Main Gastrointestinal Parasites of Poultry}

In aviculture, parasitic diseases continue to play a negative role on animal health and welfare, affecting farms productive results. The most prevalent parasitic agents are protozoa from the genus Eimeria and helminths such as Ascaridia galli, Capillaria spp. and Heterakis gallinarum (Ensuncho et al., 2015; Afolabi et al., 2016; Berhe et al., 2019) (Figure 2).

\section{Coccidia}

Coccidiosis is the most common and pathogenic parasitosis in the aviculture industry (Kaboudi et al., 2016). This disease is caused mainly by protozoa belonging to the genus Eimeria (Olanrewaju and Agbor, 2014). In chicken production, the following species have a relevant pathogenic and economic impact in farms: Eimeria acervulina, E. tenella, E. necatrix, E. mitis, E. brunetti and E. maxima (Kaufmann, 1996).

This parasitic disease develops on the small and large intestines of domestic birds, depending on the species, and it can be either Intestinal Coccidiosis or Caecal Coccidiosis. The first occurs in all the three sections of the small intestine and is caused by E. necatrix, E. maxima, E. brunetti, E. mitis and E. acervulina. Caecal Coccidiosis affects the caeca and is caused mainly by E. tenella, until 12 weeks of age (Kaufmann, 1996; Intervet Portugal, 2004). This disease can be symptomatic - diarrhea with blood and high mortality - or asymptomatic - decrease on the production results (Permin and Hansen, 1998).

The control of Coccidiosis can be achieved through improvements on health and nutrition handlings, vaccination programs and chemotherapy.

Strategies based on the techniques applied in farms are extremely important to prevent coccidiosis in flocks, being however frequently challenged by the high reproductive ability of coccidian and the resistance of oocysts to the main disinfection products used on house cleaning (Permin and Hansen, 1998).

Vaccination programs should be planned by having in mind factors such as the production system, animal density, prevalence of the parasitosis, availability of vaccines and the costs structure of the farm (Marangon and Busani, 2006). Vaccines for coccidiosis control contain a low amount of live sporulated oocysts, resulting 


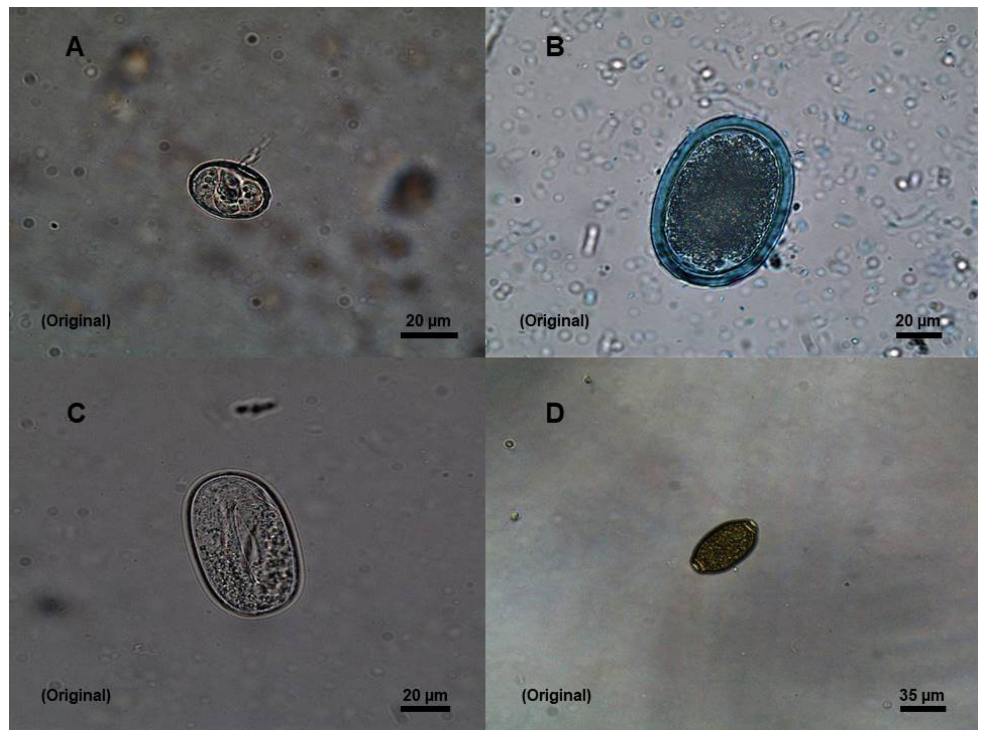

Figure 2. Oocyst (A) and eggs (B, C and D) from the most prevalent gastrointestinal parasites in aviculture, namely Eimeria sp. (A), Ascaridia sp. (B), Heterakis sp. (C) and Capillaria sp. (D) (Lozano et. al, 2018b).

in low level of infection. Coccidia proceed their normal life cycle while stimulating birds immunity (Damerow, 2015). Examples of live vaccines are Coccivac $₫$, Immucox $®$, Parcox $\AA$ and Livacox $®$ (Williams et al., 1999; Vermeulen et al., 2001).

Chemotherapy uses two types of drugs: coccidiostatic and coccidiocidal agents, which have the function of blocking the life cycle of oocysts and to destroy the parasitic forms, respectively (McDougald and Fitz-Coy, 2008). In terms of coccidiostatic drugs, Amprolium is the most used, acting as a competitive antagonist of thiamine and blocking its active and passive transport to Eimeria spp. schizonts (EMEA, 2001; DGAV, 2019). Despite Amprolium having a high accuracy against coccidia, its massive use in avicultural farms, specially with therapeutic purposes, has been the main cause for the raise of resistant coccidia, consequently limiting its use. Other drugs include ionophores such as monensin, lasalocid, salinomycin and maduramicin, nicarbazine, sulphonamides such as sulphadimidine, sulphaquinoxaline, ethopabate and clopidol, and also quinolones such as buquinolate, decoquinate, robenidine and halofuginone (Kant et al., 2013).

\section{Helminths}

Parasites with more complex biological cycles, including intermediate hosts such as snails, earthworms and insects, have a particular high economic impact in free-range systems (McDougald, 2008).

Ascaridia galli develops its action not only in the small intestine, but also in the large intestine and sometimes in the reproductive system. Examples of clinical signs are loss of appetite, feathers and weight, anemia, diarrhea and, in more severe cases, high mortality. Production conditions influence the level of infection by helminths. A regular cleaning and disinfection of the houses, is an accurate strategy to reduce the prevalence of infection by A. galli (Permin and Hansen, 1998).

The use of dewormers is restricted in the free-range system, due to the risk of accumulation of residues inside the muscle of the animals and consequent problems for the final consumer and development of resistant nematodes (Shrestha, 2013). In the European Union, only anthelminthics such as flubendazole and fenbendazole are approved to treat infections by A. galli (Tarbiat, 2018).

Helminths belonging to the genus Capillaria can be identified inside esophagus and crop (Capillaria annulata and C. contorta), small intestine ( $C$. caudinflata, $C$. bursata and $C$. obsignata) and caecum (C. anatis) (Permin and Hansen, 1998). Capillaria contorta and C. annulata are responsible for acute infections (esophagus and crop catarrhal inflammation) and soft infections (inflammation and thickening of esophagus and crop). In infections inside the small and large 


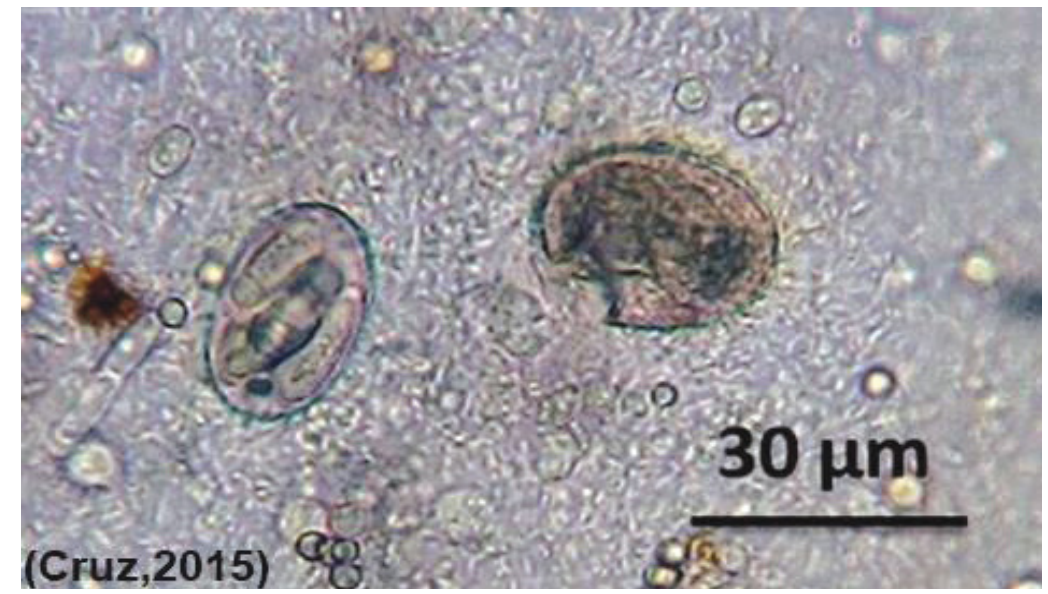

Figure 3. Two oocysts of Eimeria sp., one viable and sporulating (on the left), and the other one with its wall destroyed (on the right) and surrounded by spores of Mucor circinelloides (Cruz, 2015).

intestines, caused by Capillaria caudinflata, $C$. bursata, $C$. obsignata and $C$. anatis, animals show a loss of weight and weakness. In more acute infections, hemorrhagic enteritis and episodes of diarrhea with blood can be identified (Permin and Hansen, 1998). According to Butcher and Davis (2018), the control of Capilariosis in chicken production starts by removing intermediate hosts, such as earthworms, cleaning and disinfecting houses regularly and also deworming the flock. In terms of chemotherapy, this helminthosis can be controlled by using albendazole, ivermectin, levamisole, tetramisole, mebendazole and thiabendazole (Poultry DVM, 2018).

Heterakis gallinarum is another helminth affecting free-range poultry, which has a direct life cycle, characterized by the following steps: adult forms produce un-embryonated eggs, which are expelled to the soil with faeces; in 2 weeks, the eggs achieve the infecting stage; when ingested by the animals, larvae hatch inside the small intestine and migrate to the caecum in 24 hours; in the end, larvae achieve the adult stage, becoming essentially free in the lumen until 12 days postinfection (Yazwinski and Tucker, 2008).

In infections by $H$. gallinarum, thickening and inflammation of the caecum mucosa can be identified (Yazwinski and Tucker, 2008), as well as the formation of nodules on the mucosa, in more acute cases (Permin and Hansen, 1998). However, according to these authors, infections by $H$. gallinarum are frequently asymptomatic.

The main negative impact of $H$. gallinarum in the aviculture industry is due to its ability to carry the microorganism responsible for the "BlackHead" disease, Histomonas meleagridis (Goater et al., 2014). Histomonosis initially affects caecum and the liver, causing the necrosis of tissues. Despite affecting turkeys with more frequency, hosts such as chickens, hens, ducks, and others, can be also susceptible to this infection. Clinical signs such as yellow faeces and a dark skin, are characteristic of this disease (Jacob, 2015).

Prophylactic and treatment programs are applied mainly to control Histomonosis. However, in terms of chemotherapy, antihistomonal drugs were banned in countries with tight regulation on pharmaceuticals, several years ago, leading to the search for alternative solutions, such as hygiene, plant-derived compounds and vaccination (Liebhart et al., 2016).

\section{New Parasitosis Control Strategies}

The rise of multi-drug resistance in the common parasitic species affecting farm animals, together with the pathogenic activity of those microorganisms (Permin and Hansen, 1998), stimulated the search for alternative solutions, namely the use of nematophagous fungi (Verissimo, 2008; Mendoza de Gives and Valero Coss, 2009).

These fungi are more frequently administrated per os, in the form of spores. They resist to the passage through the gastrointestinal system and are expelled with faeces, in which they develop their activity against parasitic agents (oocysts, eggs and larvae) (Figure 3). As an alternative, spores can be distributed in the environment, namely on the soil and grass (sometimes inoculated in plant 
seeds), producing the nematophagous activity described previously (Madeira de Carvalho et al., 2007, Madeira de Carvalho et al., 2012; Miguélez Riadigos et al., 2014; Cortiñas et al., 2015; AguilarMarcelino et al., 2016). This type of parasite control consists in one of the most known examples of biological control of domestic and wild animals parasites (Cruz, 2015; Evangelista, 2018).

\section{Literature Review}

Several studies have been performed worldwide on this area, most of them aiming to identify gastrointestinal parasites in poultry produced under intensive and extensive conditions.

A study performed at Ethiopia by Chalchisa and Deressa (2016) aimed to establish associations between risk factors such as the age and production system, with episodes of Coccidiosis. In the flock analyzed $(\mathrm{N}=384)$, almost $40 \%$ was infected by coccidia and the prevalence of positive cases of oocysts was significantly higher in younger animals ( 3 to 18 weeks of age), in comparison to older chickens (more than 18 weeks). Also, the prevalence of positive cases was higher in housed animals, in comparison with chicken produced outdoor. This study showed that Coccidiosis is a reality in both production systems, as well as highlights the need to control and prevent this disease, having in mind several risk factors.

In a study performed in Poland, the authors analyzed the prevalence of gastrointestinal parasitosis in free-range chickens. Infected animals were detected in 9 of 10 farms, having been identified Eimeria spp. oocysts and helminths like Ascaridia galli and Heterakis gallinarum, with frequencies of $32.7 \%, 9.6 \%$ and $5.7 \%$, respectively. This study allowed once again to alert for the need to implement more accurate prophylactic strategies (Tomza-Marciniak et al., 2014).

In Northwestern Colombia, a study performed by Marín-Gómez and Benavides-Montaño (2007) also aimed to identify parasites in chicken produced under typical rural free-range systems, analyzing a total of 86 properties and 2046 animals. In terms of gastrointestinal parasites, a high prevalence of Eimeria spp. was detected (67.4\%), as well as nematodes such as H. gallinarum (34.9\%), A. galli (30.2\%) and Capillaria spp. (25.6\%). This study concluded that there is a correlation between the prevalence of parasites detected and the sanitary conditions of farms, as well as, the absence of prophylactic measures.

A Brazilian study conducted by Siqueira and Marques (2016), in Rio Grande do Sul, aimed also to determine the prevalence of gastrointestinal parasites in free-range chickens. Thirteen of the 14 selected farms had their animals infected by gastrointestinal parasites and in $55.4 \%$ of the infected birds were identified eggs from genus like Capillaria, Heterakis and Ascaridia. Oocysts of Eimeria spp. were also identified. However, no health problems were detected in the flocks.

Another study performed in Brazil by Serafim Da Silva, et al. (2018) aimed to evaluate helminth infections occurred in different avian production systems. A total of 374 domestic birds were assessed, belonging to 74 different properties in southeastern Brazil. Fifteen helminth species were detected in the analyzed sample, most of them present in faecal elements from birds produced under extensive conditions. Cestodes like Amoebotaenia cuneata, Choanotaenia infundibulum, Hymenolepis sp., Raillietina cesticillus, Raillietina echinobothrida and Raillietina tetragona, nematodes like Ascaridia galli, Capillaria sp., Cheilospirura hamulosa, Heterakis gallinarum, Strongyloides sp., Oxyspirura mansoni and Tetrameres confuse, and also the trematode Zygocotyle lunata, were identified in samples collected from outdoor birds. These results allowed to highlight the need for better biosecurity measures for the prevention and control of parasitosis caused by helminths, specially in freerange systems.

Seasonality of parasitism in farms is a reality and several authors aimed to establish a correlation between the prevalence of coccidia and helminths, and some weather variables, such as temperature, moisture and rainfall.

Khan et al. (2006) performed a study in Islamabad, Pakistan, in which they aimed to correlate the prevalence of coccidia from chickens, layers and hens, with some facts, namely the weather. On this work, authors obtained the highest frequencies of coccidia on September, October and November $(89.74 \%, 84.61 \%$ and $82.97 \%$, respectively), mainly due to higher values of moisture, a characteristic of those months at those countries, which accelerated the sporulating activity of oocysts and their propagation among the animals. 
In terms of helminths prevalence and their correlation with the weather, Percy et al. (2012) analyzed 60 free-range chickens in Zimbabwe, having detected infections by gastrointestinal nematodes such as A. galli, $H$. gallinarum and $C$. obsignata. Infections by A. galli where significantly higher during summer time and authors suggested that weather conditions stimulated the development of larvae and the rise of their intermediate hosts, namely earthworms. With this study, the authors pointed out the need for strategic prophylactic measures according to different weather conditions through the year.

In Portugal, Baptista (2010) performed an identification of ectoparasites and endoparasites in free-range chickens. Samples were collected from three age groups: from the day animals start contacting with the outdoor environment, until 60 days, from 61 days until 75 days and from 76 days until slaughtering age. The most frequent parasites were coccidia, namely E. mitis, and helminths such as A. galli and H. gallinarum. This study alerted for the need to improve prophylactic strategies and adapt them to the stage of the production cycle. Also in Portugal, Lozano et al. (2018a) conducted a study with free-range chicken at the fattening stage. Two samplings were performed, at 75 and 85 days of age, having obtained a global prevalence of $40 \%$ for coccidia, on the first sampling moment. On the 2nd collection, coccidia continued to be the most frequent parasites $(90 \%)$, having also been identified eggs of Heterakis sp. and Capillaria sp. Climate conditions verified between the two sample collections (high rainfall and moderate temperatures), the age and animal density, as well as the exposure to parasites with short prepatent periods, were key-factors for the increase of parasite frequencies.

\section{Conclusion}

In Free-Range Poultry Production, several factors influence the prevalence of different parasitic groups, such as the type of production system, age and animal density, hygienic conditions and also weather variables, such as temperature, moisture and rainfall.

Consumer plays a big role on the development of production systems and its recent preference for healthier and more natural sources of food, followed by the continue exponential growth of the human population and the rise of microorganisms resistant to the most common drugs used in poultry production, poses a huge challenge for alternative production systems and stimulates the search for new prophylactic and treatment strategies for the control of the main parasitosis affecting free-range chickens, namely the use of natural compounds and biological control.

Acknowledgments. The authors acknowledge the funding of their research by Project UID/ CVT/276/2019 (CIISA-FCT) and CESAM (UID/ AMB/50017/2019), FCT/MCTES through national funds, co-funding by the FEDER, within the PT2020 Partnership Agreement and Compete 2020.6.

\section{References}

1. Afolabi OJ, Simon-Oke IA, Olasunkanmi AO (2016) Intestinal Parasites of Domestic Chicken (Gallus gallus domesticus) in Akure, Nigeria. Journal of Biomedicine. 1(4):1-4

2. Aguilar-Marcelino L, Mendoza de Gives P, TorresHernández G, López-Arellano ME, Becerril-Pérez CM, Orihuela-Trujillo A, Torres-Acosta J F J, Olmedo-Juárez A (2016). Consumption of nutritional pellets with Duddingtonia flagrans fungal chlamydospores reduces infective nematode larvae of Haemonchus contortus in faeces of Saint Croix Lambs. Journal of Helminthology, 91(6):665-671.

3. Baptista AF (2010). Perfil parasitológico em frangos do campo. Dissertação de Mestrado. Universidade Técnica de Lisboa. Faculdade de Medicina Veterinária. Lisboa. Portugal. 113 pp.

4. Berhe M, Mekibib B, Bsrat A, Atsbaha G (2019). Gastrointestinal Helminth Parasites of Chicken under Different Management System in Mekelle Town Tigray Region, Ethiopia. Journal of Veterinary Medicine. doi: $10.1155 / 2019 / 1307582$.

5. Butcher GD, Davis MA (2018). Intestinal and Tracheal Parasites of Poultry. Animal Sciences Department - UF/ IFAS Extension. University of Florida. 1-3 pp.

6. Chalchisa T, Deressa FB (2016). Poultry coccidiosis: Prevalence and associated risk factors in extensive and intensive farming systems in Jimma Town, Jimma, Ethiopia. Journal of Veterinary Medicine and Animal Health, 8(12):223-227.

7. Cortiñas FJ, Cazapal-Monteiro CF, Hernández JA, Arroyo FL, Miguélez S, Suárez J, López de Arellano ME, SánchezAndrade R, Mendoza de Gives P, Paz-Silva A, Arias MS (2015). Potential use of Mucor circinelloides for the biological control of certain helminths affecting livestock reared in a care farm. Biocontrol Science and Technology, 25:12. 1443-1452.

8. Cruz RM (2015). Atividade de fungos sobre ovos, larvas e oocistos de parasitas de ungulados silvestres e do cão. Dissertação de Mestrado. Universidade de Lisboa. Faculdade de Medicina Veterinária. Lisboa. Portugal. 114 pp. 
9. Damerow G (2015). Chapter 7 - Diseases Caused by Protozoa - Vaccination. 208 pp. In Damerow, G. The Chicken Health Handbook. 2nd Edition. Storey Publishing. US. pp.487.

10. DGAV (2019). Amproline - Resumo das características do medicamento. MEDVET. Direção Geral de Alimentação e Veterinária. 3-4 pp.

11. EMEA (2001). Amprolium - Summary Report. Committee for Veterinary Medicinal Products. The European Agency for the Evaluation of Medicinal Products. pp.1

12. Ensuncho HC, Herrera B Y, Montalvo PA, Almanza PM, Vergara ÁJ, Pardo RE, Gómez ML (2015). Frecuencia de Parásitos Gastrointestinales en Gallinas Criollas (Gallus domesticus) en el Departamento de Córdoba, Colombia. Revista Electrónica de Veterinaria - REDVET, 16(6):1-9.

13. Evangelista F (2018). New administration formula of parasiticide fungi spores to prevent infection by gastrointestinal nematodes in pasturing horses. MSc dissertation. Faculty of Veterinary Medicine. University of Lisbon. 60 pp.

14. Filho PH, Menten JFM, Neves da Silva MA, Coelho AAD, Savino VJM (2003). Efeito de Genótipo e do Sistema de Criação sobre o Desempenho de Frangos Tipo Caipira. Revista Brasileira Zootécnica. 32(6):.1883-1889.

15. Goater TM, Goater CP, Esch GW (2014). Nematoda: The roundworms. 228 pp. In Goater, T. M., Goater, C. P. and Esch, G. W. Parasitism - The Diversity and Ecology of Animal Parasites. 2nd Edition. Cambridge University Press. UK. pp 497.

16. Intervet Portugal (2004). Doenças mais importantes das aves. Intervet Portugal - Saúde Animal, Lda. Sintra. 88 pp.

17. Jacob J (2015). Blackhead in Poultry. Small and Backyard Flocks. eXtension. USA. Accessed on: 10/08/2018. URL: http://articles.extension.org/pages/68108/blackheadin-poultry

18. Khan MQ, Irshad H, Anjum R, Jahangir M, Nasir U (2006). Eimeriosis in Poultry of Rawalpindi/Islamabad Area Pakistan Veterinary Journal. 26(2):85-87.

19. Kant V, Singh P, Verma PK, Bais I, Parmar M S, Gopal A Gupta V (2013). Anticoccidial Drugs Used in the Poultry: An Overview. Science International, 1: 261-265, DOI: 10.17311/sciintl.2013.261.265

20. Kaufmann J (1996). Parasitic Infections of Domestic Animals. Birkhäuser Verlag. Basileia. Suíça. 393 pp.

21. Liebhart D, Ganas P, Sulejmanovic T, Hess M (2016) Histomonosis in poultry: previous and current strategies for prevention and therapy. Avian Pathology,46(1):1-18.

22. Lozano J, Gomes L, Madeira de Carvalho LM (2018a). Parasitas gastrointestinais em produção de frango ao ar livre. Revista Portuguesa de Ciências Veterinárias. 113 (605-606):18-28.

23. Lozano J, Palomero Salinero A, Díaz AAM, Paz-Silva A, Madeira de Carvalho LM (2018b). Controlo Biológico de Parasitas Gastrointestinais em Avicultura Extensiva. Revista Albéitar. Publicações Ciência e Vida. 6: 34-38.

24. Lozano J, Mourato J (2016). Produção de Frango do Campo - Relatório da Visita a uma exploração avícola. Unidade
Curricular de Produção de Aves e Suínos. Instituto Superior de Agronomia. Universidade de Lisboa. pp 15.

25. Madeira de Carvalho LM, Bernardo FA, Paz-Silva A (2012). The role of fungi in the control of animal parasites classification, mode of action and practical applications. 271-308 pp. In Paz-Silva, A., Vázquez, M. S. A. (Eds.). Fungi: Types, Environmental Impact and Role in Disease. Nova Science Publishers. Hauppauge, New York.

26. Madeira de Carvalho LM, Gillespie AT, Serra PM, Bernardo FA, Farrim AP, Fazendeiro I (2007). Eficácia do fungo nematófago Duddingtonia flagrans no controlo biológico da estrongilidose equina no Ribatejo. Revista Portuguesa de Ciências Veterinárias. 102 (563-564):233-247.

27. Marangon S, Busani L (2006). The use of vaccination in poultry production. Revue scientifique et technique International Office of Epizootics, 26(1):265-274.

28. Marín-Gómez SY, Benavides-Montaño JA (2007). Parásitos en aves domésticas (Gallus domesticus) en el Noroccidente de Colombia. Vet Zootec, 1(2):43-51.

29. McDougald LR (2008). Protozoal infections. 10771080 pp. In Saif, Y. M. Diseases of Poultry. 12th Edition. Blackwell Publishing. USA. pp 1409.

30. McDougald LR, Fitz-Coy SH (2008). Internal Parasites. 1025 pp. In Saif, Y. M. Diseases of Poultry. 12th Edition. Blackwell Publishing. USA. pp 1409.

31. Mendoza de Gives P, Valero Coss MCRO (2009). Uso de Hongos Nematófagos: Una Herramienta Biotecnológica para el Control de Nematodos Parásitos del Ganado. Folleto Técnico № 7 - Instituto Nacional de Investigaciones Forestales, Agricolas y Pecuarias. Centro Nacional de Investigación Disciplinaria en Parasitología Veterinaria. pp 8-10.

32. Miguélez Riádigos S, Arias Vázquez M S, Valderrábano Cano E, Piñeiro Fraga P, Gómez Uzal D, Fernández Marcos M, Bonilla Quintero R, Sánchez-Andrade Fernández R, Madeira de Carvalho LM (2014). Control biológico de nematodos parásitos en antílopes (Cervicapra cervicapra) en cautividad. Revista Pastagens e Forragens, 34:47-56.

33. Olanrewaju CA, Agbor RY (2014). Prevalence Of Coccidiosis Among Poultry Birds Slaughtered at Gwagwalada Main Market, Abuja, FCT, Nigeria. The International Journal of Engineering And Science, 3(1):41-45.

34. Percy J, Pias M, Enetia BD, Lucia T (2012). Seasonality of parasitism in free range chickens from a selected ward of a rural district in Zimbabwe. African Journal of Agricultural Research,7(25):3626-3631.

35. Permin A, Hansen JW (1998). Epidemiology, Diagnosis and Control of Poultry Parasites - FAO Animal Health Manual; Food and Agriculture Organization of the United Nations (FAO); Roma, Itália. pp. 3,9-11,23-30,48-54.

36. Poultry DVM (2018). Drugs and Medications. Accessed on: 05/06/2019. URL: http://www.poultrydvm.com/drugs

37. Serafim Da Silva G, Romera D M, Conhalato GS, Soares VE, Meireles MV (2018). Helminth infections in chickens (Gallus domesticus) raised in different production systems in Brazil. Veterinary Parasitology: Regional Studies and Reports. 12, pp 55-60. 
38. Shrestha A (2013). Feeding Strategy and Genotypic Effects on Susceptibility to Ascaridia galli in Organic Layers. Master Thesis. Aarhus University. Denmark. pp 14.

39. Siqueira GB, Marques SMT (2016). Parasitos intestinais em galinhas caipiras da região metropolitana de Porto Alegre, RS. Publicações em Medicina Veterinária e Zootecnia, 10(9):690-695.

40. Tarbiat B (2018). Ascaridia galli in laying hens: Adaptation of a targeted treatment strategy with attention to anthelminthic resistance. Doctoral thesis. Swedish University of Agricultural Sciences, Uppsala. 55 pp.

41. Tomza-Marciniak A, Pilarczyk B, Tobianska B, Tarasewicz $N$ (2014). Gastrointestinal parasites of free-range chickens. Annals of Parasitology. Polish Parasitological Society. 60(4):305 - 308.
42. Verissimo CJ (2008). Alternativas de Controle da Verminose em Pequenos Ruminantes. Instituto de Zootecnia - Nova Odessa. pp 83-106.

43. Vermeulen AN, Schaap DC, Schetters TPM (2001). Control of coccidiosis in chicken by vaccination. Veterinary Parasitology, 100:13-20.

44. Williams RB, Carlyle WW, Bond DR, Brown IA (1999). The efficacy and economic benefits of Paracox, a live attenuated anticoccidial vaccine, in commercial trials with standard broiler chickens in the United Kingdom. International Journal for Parasitology, 29(2):341-355.

45. Yazwinski TA, Tucker CA (2008). Nematodes and Acanthocephalans. 1042-1043 pp. In Saif, Y. M. Diseases of Poultry. 12th Edition. Blackwell Publishing. USA. pp 1409. 